\title{
IMPACT OF BIG DATA ON DEVELOPMENT OF THE CURRICULUMS OF TRAINING STATISTICIANS IN UKRAINIAN UNIVERSITY
}

\author{
$\underline{\text { Ruslan }}$ Motoryn $^{1}$, Tetiana Motoryna ${ }^{2}$, and Kateryna Prykhodko ${ }^{2}$ \\ Kyiv National University of Trade and Economics, Ukraine \\ Taras Shevchenko National University of Kyiv, Ukraine \\ motoryn@i.ua
}

In the Soviet era in Ukraine, theoretical subjects dominated in the education curriculum. Since independence, there have been profound changes in the higher education system of Ukraine. The system has adapted to the market model, with an increasing number of applied disciplines such as data mining, software engineering and data visualization. Courses should cover both theoretical knowledge and practical skills. Recently, one of the top requested areas at the information technology market is the processing of large data sets (Big data). Many leading universities of Ukraine, including Taras Shevchenko National University of Kyiv and Kyiv-Mohyla Academy, plan to establish courses of data mining, statistics, and data visualization. For now, however, universities do not have enough teachers. Therefore, under the scope of the Ukrainian Distance Education Project "Prometheus", in 2017 an online course on the Big Data will be launched. This paper will summarize the curriculum developed by the authors, in courses on Business Analytics, Software Engineering, Data Analysis, and Data Visualization. 